\title{
PRELIMINARY NOTE ON A SURVEY OF STOKE POINT ROCKS WITH SELF-CONTAINED DIVING APPARATUS
}

\author{
By G. R. Forster
}

The Plymouth Laboratory

(Text-fig. I)

It has long been recognized that a proper knowledge of the fauna of submerged rocks can be obtained satisfactorily only by direct study with diving apparatus (Gislen, I930; Kitching et al., 1934). Although the latest methods of indirect underwater observation, photography and television, may be useful on a smooth sea floor, they can give little information about a rocky area owing to their inability, as yet, to look underneath a boulder or an overhanging ledge. The superiority of the 'submarine biologist' over the indirect methods lies in the fact that he can readily collect samples for positive identification, or mark individual organisms for further study; though at present, unless very expert, he is limited to depths of under 20 fathoms. The successful use of free-diving apparatus for biological work is well established. Five years ago Prof. Drach with Cousteau's now famous 'aqualung' investigated the sublittoral fauna of various rocky shores, reaching a depth of $30 \mathrm{~m}$. (Drach, 1948). Much additional work has been done in the Mediterranean and other warm seas, while farther north Bainbridge (1952) used a Siebe-Gorman apparatus to study the behaviour of plankton in the Clyde.

My training was carried out at the Portsmouth and Plymouth Royal Naval diving establishments. In 1952 a Siebe-Gorman 'aqualung' was purchased with the aid of a Royal Society apparatus grant. This breathing set, combined with a S.-G. light two-piece waterproof suit formed the equipment used during a survey in 1953 .

The area of Stoke Point rocks was selected as being the most suitable locality for studying the fauna and flora which replace Laminaria hyperborea (Gunn) Fosl. at a depth of about Io fathoms (see Chapman, 1944), since in less than Ioo yards the depth increases from 6 to I2 fathoms. The exact position is: distance from Stoke Point, MHWST, 0.40 sea mile, bearing $146^{\circ} \mathrm{T}$. After considerable practice, the sub-Laminaria zone was reached in August 1953, but only six dives were made during the period from August till October, owing to bad weather restricting the already limited opportunities to use the research vessels. The results are thus based on a total period of but 2 hours 'diving time' and refer only to the larger and more conspicuous organisms.

The results are shown diagrammatically in Fig. I. Laminaria hyperborea is 


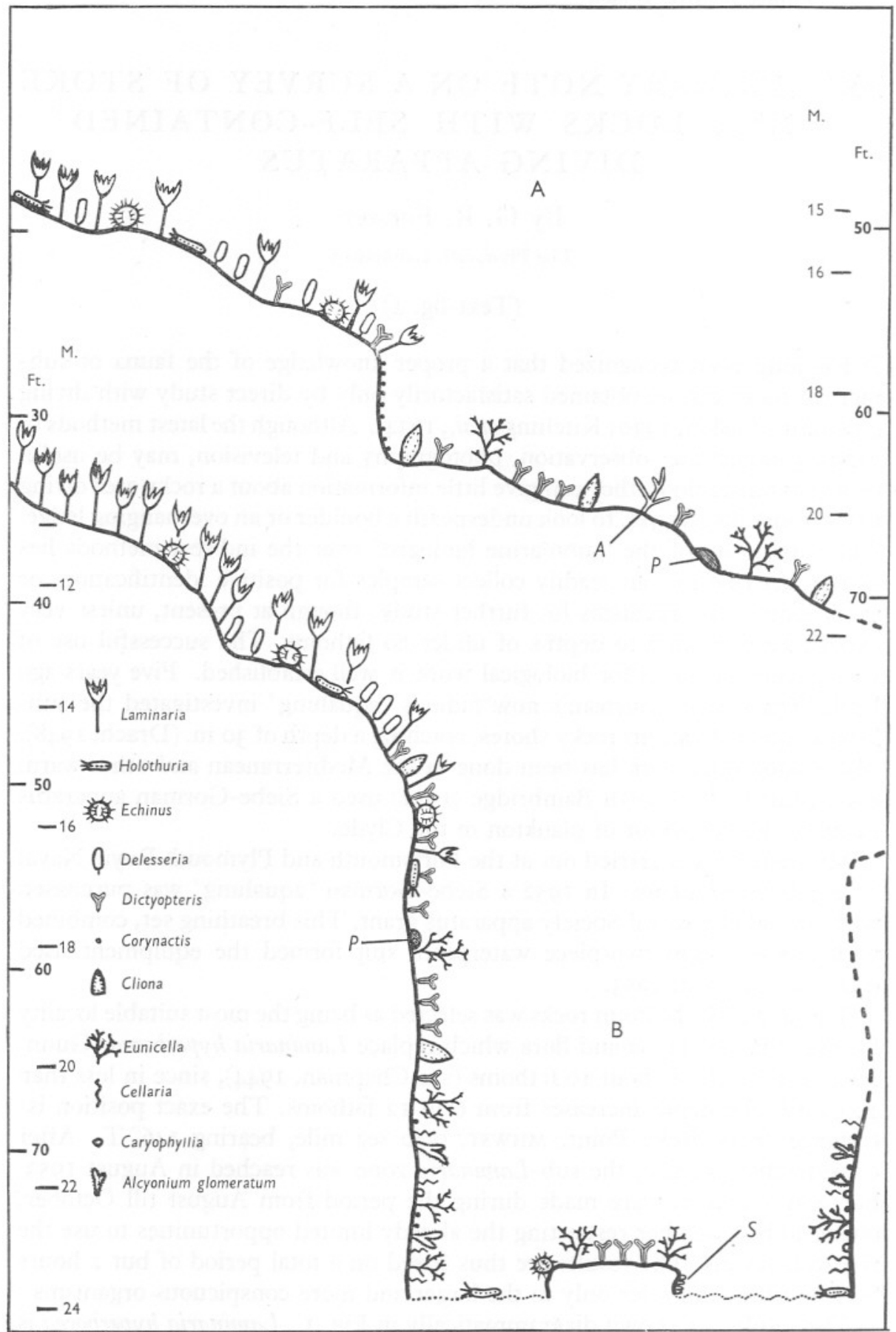

Fig. I. Diagrammatic profiles of rocks at Stoke Point, S. Devon. The depths are given as feet and metres below chart datum, i.e. MLWST Devonport. The horizontal scale is approximately the same.

A, profile of reef Ioo yards north-west of gully;

$\mathrm{B}$, profile of the gully. Key inset above. A, Axinella; P, Pachymatisma; S, Stolonica socialis. 
clearly the dominant form to a depth of $50 \mathrm{ft}$. below low water (C.D.). At 35-40 ft. a few Echinus esculentus L. appear, together with Holothuria forskali Delle Chiaje, though unlike Echinus, Holothuria is occasionally taken intertidally in the Plymouth area. Below $50 \mathrm{ft}$. the Laminaria is sparse and Delesseria sanguinea (Huds.) Lamour. becomes abundant, both plants being heavily encrusted with Bryozoa. The Delesseria is replaced at about $55 \mathrm{ft}$. by a thin carpet of the brown weeds, Halopteris filicina (Grat.) Kütz. and especially Dictyopteris membranacea (Stackh.) Batt., neither of which suffer from Bryozoa or epiphytes. At this depth large yellow colonies of the sponge Cliona celata Grant are seen, together with the smooth grey Pachymatisma johnstoni Bowerbank, which in shallower water is confined to crevices or shaded positions. The conspicuous pink or flesh-coloured colonies of Eunicella verrucosa (Pallas) appear at around $65 \mathrm{ft}$. These 'sea fans' were always orientated in a nearly vertical plane, thereby presenting the maximum area to the tidal stream. In the gulley (Fig. I B) Eunicella reaches a maximum frequency of very roughly 2-4 per square metre, from Io ft. above to I ft. above the bottom: the lowermost foot was, at least in several places, completely bare due presumably to abrasion by the coarse sand of the gulley floor. In this area where the Eunicella flourishes, the Dictyopteris is distinctly sparse, the ground layer being composed largely of Bryozoa, especially Cellaria sp., some encrusting sponges and many Corynactis viridis Allman. Almost as numerous as the Eunicella is Alcyonium glomeratum (Hassal), whose snow-white polyps make a bright contrast against the otherwise deep red surface of the colony. The rarity of this species in dredgings is probably explained by the fact that it has not been seen outside the gully. At the same depth as the Alcyonium and Eunicella, a few large solitary ascidians Phallusia mamillata (Cuvier) appear, and occasional colonies of ross (Lepralia pallasiana (Moll.)), the tubicolous polychaete Filograna implexa (Berkeley) and the yellow branching sponge Axinella dissimilis (Bowerbank).

\section{SUMMARY}

A preliminary survey has been made, near Stoke Point, S. Devon, of the rock fauna at depths below the Laminaria belt, with self-contained compressed-air diving apparatus. By this method much more exact records of the distribution, and general abundance of the commonest species, have been obtained than would be possible with dredgings. It is hoped to make a greatly extended survey in the future. 


\section{REFERENCES}

BAINBRIDGE, R., I952. Underwater observations on the swimming of marine zooplankton. F. Mar. biol. Ass. U.K., Vol. 31, pp. 107-I2.

Chapman, V. J., I944. Methods of surveying Laminaria beds. F. Mar. biol. Ass. U.K., Vol. 26, pp. 37-60.

DrACH, P., I948. Premières recherches en scaphanale autonome sur le peuplement des faciès rocheux de la zone littorale profonde. C.R. Acad. Sci., Paris, T.227, pp. $1176-8$.

Gislen, T., 1930. Epibioses of the Gullmar Fjord. I. A study in marine sociology. Kristinebergs Zoologiska Station 1877-1927 (Jubilee Memoir), Nr. 3, I23 pp.

Kitching, J. A., MaCan, T. T. \& Gilson, H. C., I934. Studies in sublittoral ecology. I. A submarine gully in Wembury Bay, South Devon. F. Mar. biol. Ass. U.K., Vol. 19, pp. 677-705. 